\title{
The relationship between Business Process Management and Knowledge Management - selected aspects from a study of companies in Poland
}

\author{
Agnieszka Bitkowska ${ }^{1}$
}

\begin{abstract}
The integration of the concepts of Business Process Management (BPM) and Knowledge Management (KM) is a challenging research issue today, and should be analyzed jointly in contemporary enterprises. The challenge for modern process organizations is the constant accumulation of knowledge and its skillful use in order to gain a competitive advantage and ensure a stable position in the market. Despite the growing interest among researchers and practitioners there is a lack of articles in this area. The main objective of this paper is to identify the relation between Business Process Management and Knowledge Management. The article presents the results of empirical research conducted by the author in contemporary enterprises in Poland in 2019, and some solutions, as well as benefits, related to the correlation of these two concepts. Business Process Management has a positive influence over Knowledge Management processes. The identification, acquisition, presentation and documentation of knowledge are not independent tasks, but are implemented within processes. The implementation of Knowledge Management stimulates employee creativity and supports internal communication. Building a process organization using best practices and guidelines minimizes the risk of failure of projects to improve the organization and implement Knowledge Management. In order to test the correlations between them, Yule's, Pearson's, and Bykowski's coefficients have been used.

Keywords: business process management, knowledge management, knowledge management process
\end{abstract}

1 Agnieszka Bitkowska, doctor habilitatus, prof. Warsaw University of Technology - Faculty of Management, ul. Narbutta 85, 02-524 Warsaw, Poland, e-mail: Agnieszka.Bitkowska@pw.edu.pl (ORCID ID: https://orcid.org/0000-0002-2817-8244). 


\section{INTRODUCTION}

Under the circumstances surrounding the highly volatile economy of the 21st century, the business environment is unpredictable. In order to preserve a competitive market position, it is necessary to continuously improve an organization. Dynamically changing environmental conditions - the development of information technologies and processes of digitization, knowledge economy, globalization and challenges resulting from the fourth technological revolution - create new opportunities for the development of enterprises, and at the same time the need to create appropriate adaptation mechanisms.

In a knowledge-based economy, traditional resources, such as labor or capital, play a smaller role. Knowledge is a valuable asset of contemporary organizations that underlies the organization's activity in all its aspects and dimensions (Gierszewska, 2011; Zięba, 2017). Today's organizations are more aware than ever of the dependence of their competitiveness on their intellectual resources and key competences. Knowledge - one of the most important determinants of competitiveness - has a direct impact on the success of any organization (Gierszewska, 2018).

One of the concepts here is Business Process Management (BPM) (Burlton, 2001; Harmon, 2007; Jeston \& Nelis, 2014; Pyzdek \& Keller, 2009; Smith \& Fingar, 2003). It has become the inspiration and foundation of many researchers as well as application initiatives over more than a dozen recent years. As far as the theory of management is concerned, one of the trends in organizational management is process approach which comprehensively and horizontally attends to the structure of an organization (Rummler \& Brache, 1995). Business Process Management in an organization should take into account the knowledge resources that the organization possesses in order to ensure that employees have access to knowledge regarding specific tasks which are part of particular business processes (Maier \& Remus, 2002; Ho, Hsieh, \& Hung, 2014; Jung, Choi, \& Song, 2007). Therefore, the processes occurring in an organization should be increased, based on individual, team, and organizational knowledge and, consequently, they become more and more flexible as well as adjusted to the changing environmental conditions (Richter-von Hagen, Ratz, \& Povalej, 2005; Gabryelczyk \& Roztocki, 2018).

The main objective of this paper is to identify the relation between Business Process Management and Knowledge Management (KM) through the Knowledge Management process in contemporary enterprises. Although the idea of Knowledge Management implementation and its influence on innovation performance of organizations have been proposed (Alavi \& Leidner, 2001; Andreeva \& Kianto, 2012; Chong, Ooi, Lin, \& Teh, 
2010; Lundvall \& Nielsen, 2007; Pastuszak \& Chadam, 2013; Yin-Kuan, Ng, Voon-Hsien, Lee, Alex, \& Pei-Lee Gan, 2012), the approaches that focus on Knowledge Management within the business process level are limited (Wiig, 1995; Papavassiliou \& Mentzas, 2003). Currently, to the best of one's knowledge, such an overview and such an analysis of BPM standards have not so far been undertaken. Ultimately, the adoption of the process of Knowledge Management contributes to an increase in the level of innovation in organizations that are managed on the basis of processes. The main research question was formulated as:

RQ: What is the relationship between Business Process Management and Knowledge Management?

Prior to conducting analysis, the main hypothesis was put forward as:

$\mathrm{H}$ : Business Process Management has a positive influence on Knowledge Management.

From an empirical aspect, the implementation of the objectives of the article included the analysis of Business Process Management, or elements of this concept, in organizations operating in Poland. The following research techniques and methods were used: literature analysis, questionnaire. In the first stage of the work, the author made an analysis and evaluation of the Business Process Management of contemporary enterprises by conducting a methodological foundation. The next stage was the analysis of Business Process Management in contemporary organizations operating in Poland through the implementation of their own empirical research in 2019.

\section{THEORETICAL BACKGROUND}

The modern market requires organizations to be flexible. A company's ability to achieve its aims calls for successful adaptation to the changes occurring in its environment as well as for the creation of its own solutions. The ever-growing number of enterprises adapting to the conditions of their environment take advantage of a process approach, understood as orienting the company towards processes occurring within it (Antonucci \& Goeke, 2011). The process approach is a basis for introducing Business Process Management, which over the past dozen years has become an inspiration and a foundation for numerous initiatives of various types of application. The concept of Business Process Management has begun to incite greater interest 
among both theoreticians and researchers. Business Process Management (BPM) has emerged as a holistic management discipline covering processcentered technologies, modeling and analysis methods, as well as such things as strategic alignment, governance, people and culture (Rosemann \& vom Brocke, 2010). The increase in the literature related to Business Process Management, the appearance of specialist magazines (e.g., Business Process Management Journal) and conferences (e.g., BPM-Conference) as well as relevant university courses, has indicated the fact that BPM is an evolutionary trend in management studies (Ko, Lee, \& Lee, 2009). The main challenge that contemporary enterprises seem to face in the light of constant changes in the market is the complex and structuralized implementation of Business Process Management, which will enable them to reach their intended goals (Malinova \& Mendling, 2018). Definitions presented in the subject literature point to: a comprehensive approach to an organization, realized by means of management functions appropriate to the processes; connecting this approach with an organization's strategy; and undertaking actions aimed at raising efficiency while engaging human resources and information technologies. They also point to optimization, elimination of all shortcomings and inefficiencies in an organization, and a focus on creating value. Business Process Management means the systematic application of proper concepts, methods and instruments that influence the processes at their various stages - defining, modelling, implementing, controlling and enhancing - conducted in accordance with a company's strategy and encompassing the whole company with regard to its organizational, social, financial, IT and knowledge-related aspects (Bitkowska, 2013). It is essential to constantly improve processes and reformulate their concepts. The aim of it all is to create a process-based organization.

Business Process Management enables a company to adapt to the challenges posed by its environment and create new possibilities of gaining an advantage over the competition. Properly defining processes, and then modelling, implementing, controlling and enhancing them, considerably improves both a company's profitability and customer satisfaction, and consequently boosts the company's competitive potential. Using a formalized approach makes it easier for an organization's managers to carry out projects, ensuring risk reduction and enhancing the probability of achieving the intended aims. Diagnoses of needs and challenges that companies face (Antonucci \& Goeke, 2011) indicate the popularity of, and a growing demand for, processbased methods and instruments for improving an organization's effectiveness.

The development of Business Process Management is a response to the growing turbulence of the environment and the interior of the enterprise, increased complexity of internal and external processes, individualization of 
customer needs and expectations, short product-life cycles and an increase in the importance of intangible assets in creating a competitive advantage. The process stream is located in the sphere of contemporary management trends that promote decentralization, customer orientation, reorientation of the organizational structure from vertical to horizontal, which contribute to the growth of the organization's effectiveness in changing conditions (Trocki, 2016).

The main goal of Business Process Management is to improve the efficiency of operations in the enterprise by structuring activities in terms of creating added value, paying particular attention to customer preferences and needs, and the proper description and configuration of processes in the enterprise in accordance with the criteria of time and space. In many cases, meeting these requirements is not always possible due to the lack of a design approach or the need to use knowledge. The main advantage is to ensure ongoing control over the connections between individual processes in the whole system.

Contemporary organizations use Business Process Management in order to improve competitiveness, efficiency, flexibility, financial results or the quality of customer service, and the internal structure of processes. Focusing on Business Process Management, organizations improve the effectiveness of existing systems, processes and products, using the available philosophies, principles, tools and management methods. Organizations use star-standard solutions in the form of good practices, reference models, industry models, and use models of maturity which indicate further directions of development in the field of Business Process Management. Moreover, organizations use a multi-dimensional approach that includes IT, social or organizational dimensions (Hislop, 2013; Spanyi, 2005; Harmon, 2007; Smith \& Fingar, 2003). The digital transformation of business processes will require an increasing level of automation and robotization. The Business Process Management systems (BPMS) are supplemented by RPA (Robotic Process Automation), whose main task is to correct, develop and support internal processes in order to achieve maximum efficiency, but they do not replace the work done by employees (Mejssner, 2018). Opportunities in the areas of the fourth technological revolution, intensifying digitization and globalization determine changes in process-oriented enterprises. The concept of integrated Business Process Management may be responsible, taking into account anticipated projects as well as knowledge (Bitkowska, 2019a).

Knowledge Management is part of organizational management and encompasses all the processes related to the localization, acquisition, creation, transfer, application, and retention of knowledge, which serve the purposes of an organization, including analyses, planning, operational activity, and control (Donate \& Sánchez de Pablo, 2015; Tiago, Couto, Tiago, \& Vieira, 2007; Wen, 2009; Bitkowska, 2017). A process model is based on practical 
experiences and solutions that large consulting firms make use of. A large contribution to the development of the process model has been provided by Davenport and Prusak from IBM Consulting Group (1997) and Probst, Raub and Romhardt (2000). They have made a synthesis of the existing practical experiences. In line with the process model, Knowledge Management is all the processes allowing one to create, disseminate, and use knowledge in order to fulfill the purposes of an organization. There are three main phases of Knowledge Management: acquisition (creation) of knowledge, sharing knowledge, and transforming knowledge into decisions (Bitkowska, 2017). The process model used mainly by large organizations is based on methods proven in practice. There is also the so-called Japanese model (Nonaka \& Takeuchi, 1995). Knowledge Management based on the principle of a spiral is a repeating cycle of four processes of knowledge conversion: internalization, socialization, externalization, combination (Bitkowska, 2017).

Ho, Hsieh, and Hung (2014), presented an interesting integrated model which considers how knowledge enablers, (KCP - knowledge circulation processes), and individual job performances direct firms' effective application of Knowledge Management. KCP has further application by individuals to improve job performance (Lin, 2007; Liao \& Wu, 2010; Lundvall \& Nielsen, 2007; Rehman, Asghar, \& Ahmad, 2015). Gavrilova, Alsufiev and Pleshkova (2017) indicated that Knowledge Management practices are considered the key element for enhanced innovative performance.

According to Handzic (2017) the knowledge process component of the model covers various processes through which knowledge is moved (e.g., transfer person-to-person, person-to-document) and modified (e.g., creative idea generation, mining of hidden patterns in capturing data). Handzic is underlining that the better the processes of knowledge generation, sharing, capture and discovery, the greater the likelihood that the knowledge needed will be available leading to more effective and innovative organizational performance (Hanadzic, 2017; Bitkowska, 2017).

The improvement in client satisfaction and the effectiveness of services and decision making must also be highlighted. Knowledge is the inseparable resource processed as part of the processes. Knowledge is generated when organizational processes take place, such as: distribution, marketing, designing, and preparation of production. As far as knowledge created in the course of the processes of designing and preparation of production is concerned, it is technical in character. Knowledge is put to use by both the performers of processes - process team members - as well as the owners of processes (Bitkowska, 2017). Any information related to processes, such as: process models, indicators, measures, and aims, should be collected and formalized in order to contribute to the improvement and, consequently, the 
development of the whole organization (Bitkowska, 2017). An approach of a model-based design of knowledge-oriented processes proposes a reference model for Knowledge Management (see Warnecke, Gissler, \& Stammwitz, 1998). The reference model consists of an object model with system elements and activities, a process model and an implementation model.

Business process modeling - an approach to depict the way organizations conduct current or future business processes - is a fundamental prerequisite for organizations wishing to engage in business process improvement or Business Process Management initiatives (Indulska, Recker, Rosemann, Green, \& Peter, 2009; Madison, 2005). In their most basic form, process models describe, typically in a graphical way, the activities, events and control flow logic that constitutes a business process (Bosilj-Vukšic, 2006; Recker, Rosemann, Indulska, \& Green, 2009). Additional information, such as goals, risks and performance metrics for example, can also be included. Accordingly, process models are considered a key instrument for the analysis and design of process-aware Information Systems (Dumas, van der Aalst, \& Hofstede, 2005), organizational documentation and re-engineering (Davenport \& Short, 1990; Davenport, 1992), and the design of service-oriented architectures (Rabhi, Yu, Dabous, \& Wu, 2007).

Process modeling is concerned with the transformation of knowledge about the functioning of a selected (business) area in an organization, and the processes that take place within it, into the corresponding models. Lately, the market has been flooded with numerous IT solutions supporting the designing and monitoring of business. Such software aids the process of identification of tasks undertaken by individual organizational units, and allows one to create a graphic representation of a business process and simulate the course of a business process. Usually, such software ensures the possibility to prepare user interfaces in the client-server architecture, which enables control of the work of individual participants in the process. As far as a definition of a graphic representation of a business process is concerned, many various notations that support business process modelling may be used, e.g., BPMN (Business Process Modelling Notation) and BPEL (Business Process Execution Language) (Ho, Hsieh, \& Hung, 2014; Silver, 2011). One of the most popular standards of process modeling is the Business Process Modelling Notation (BPMN) (Silver, 2011; Spanyi, 2005). The currently applicable standard BPMN 2.0 was published by the Business Process Management Initiative (BPMI) in 2011.The main objective of the creation of the BPMN was the preparation of notation to describe processes, which would be easy to understand by all parties taking part in modeling, especially business analysts and software developers responsible for the implementation of solutions supporting processes, or people who possess content-related knowledge but no broad understanding 
of modeling. Some authors indicated other popular standards in modeling: UML, DMN and the models and the diagrams provided by these notations (Kluza, Wiśniewski, Jobczyk, Ligeza, \& Suchenia, 2017). Żytniewski (2016) in some research presented the integration of software agents (an element that performs and automates business processes) within business processes and the processes of knowledge. The main aim of the proposed architecture of a software solution was designed to support the modelling of business processes and improve these processes (Żytniewski, 2016, 2017).

Zhu (2015) underlines that Knowledge Management as a meta-process in relation to BPM if KM is placed on top of BPM. In this perspective, Knowledge Management is used at the strategic level as a generator, amplifier and accelerator of value creation (Steve, 2019). This means KM improves BPM performance as a process, riding on top of business process improving and accelerating the creation of value (Zhu, 2015). In this case, knowledge is the critical component in the business process. Linderman, Schroeder, and Sanders (2010) indicated the link between process management systems and knowledge creation, and Martínez-Martínez, Luis, Suárez, Montero, and del Arco (2018) underlined that Knowledge Management is a tool for improving business processes.

With digitalization, more and more data and information will be generated in a shorter time, which should be collected and processed into internal knowledge in order to be competitive (Paschek, Ivascu, \& Draghici, 2018). Through the variety of data and information, a well-grounded knowledge database can be developed and used for the adoption and optimization of Business Processes. It is recognized that KM plays an essential role as a background for the better management, adjustment and implementation of processes (Paschek, Ivascu, \& Draghici, 2018) (Figure 1).

Business Process Management has emerged as a well-respected variable in the design of high-performance organizations (Franz, Kirchmer, \& Roseman, 2012). Managerial variables such as products and services, customers and employees, and physical or digital assets (e.g., data and information), the conceptualization and management of business processes still face some fundamental challenges (Franz, Kirchmer, \& Roseman, 2012). One of these is the link between BPM activities and their contribution to corporate value (efficiency, compliance, integration, quality, agility, networking) (Figure 2, Table 1). 


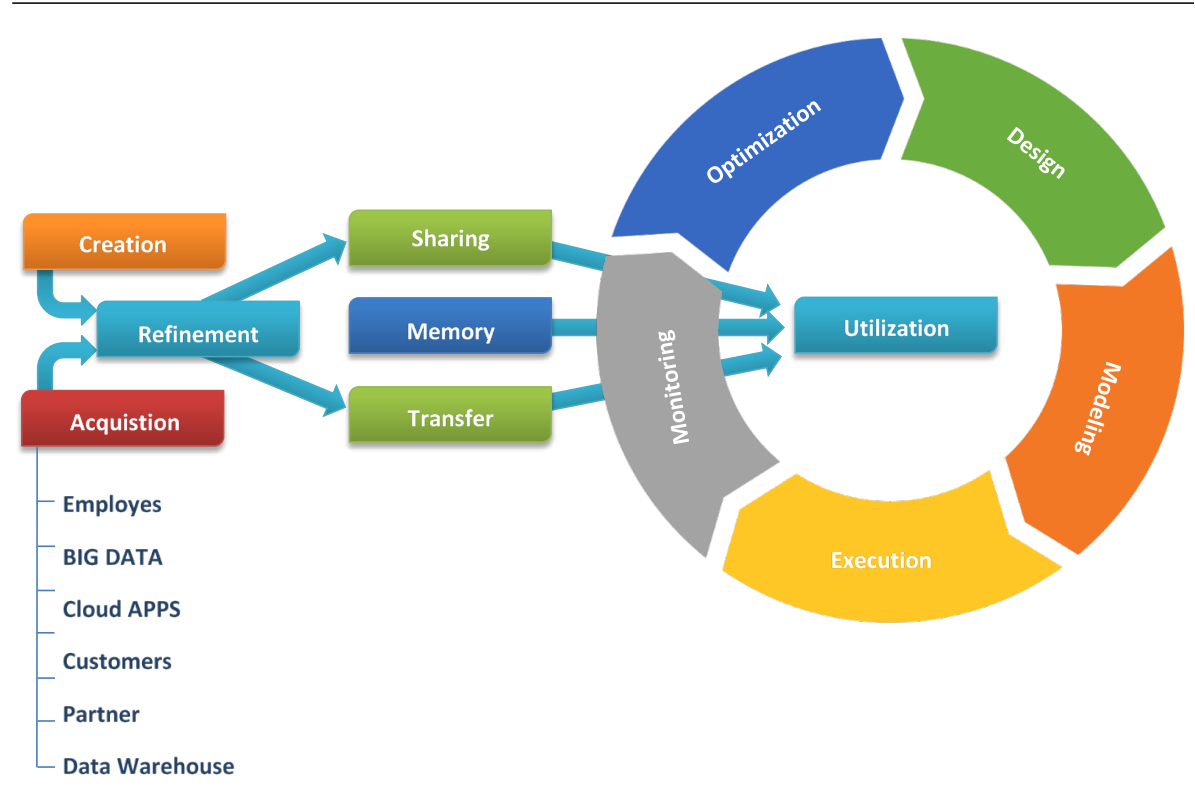

Figure 1. KM - BPM Process Model

Source: Paschek, Ivascu, \& Draghici (2018).

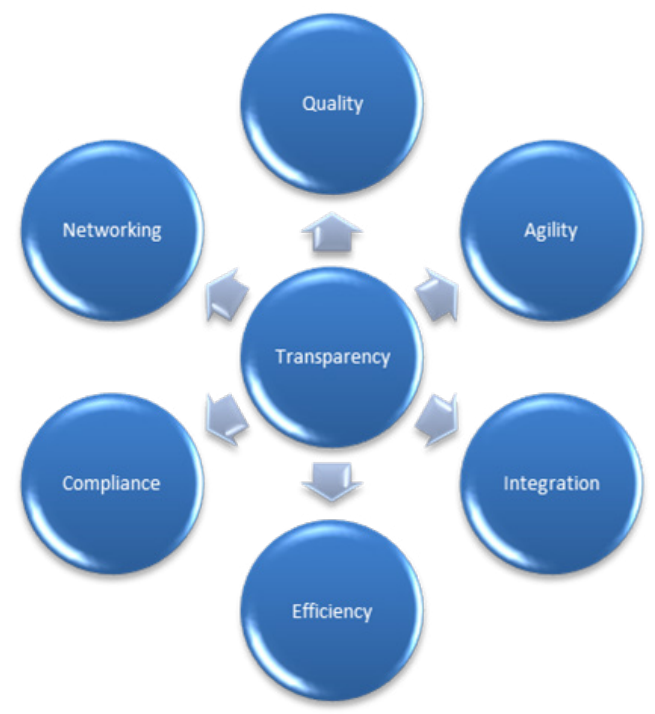

Figure 2. Value-driven Business Process Management (VBPM)

Source: based on Franz, Kirchmer, \& Rosemann (2012). 
Table 1. Characteristics the values of BPM - Transparency

\begin{tabular}{ll}
\hline Type & Characteristics \\
\hline A process model repository & $\begin{array}{l}\text { That is scalable, supports user and user group } \\
\text { management, covers current process modeling } \\
\text { standards, but can be customized, and allows } \\
\text { publishing models via various channels (for } \\
\text { example, over an intranet) }\end{array}$ \\
The design of process models & $\begin{array}{l}\text { That is intuitive to relevant stakeholders in } \\
\text { terms of their graphical design. This will typically } \\
\text { require extensions and improved visualizations } \\
\text { to make the dominant process modelling } \\
\text { techniques such as business process modeling } \\
\text { notation (BPMN) and event driven process chain } \\
\text { (EPC) easier to understand. }\end{array}$ \\
Widely disseminated models & $\begin{array}{l}\text { That is easy to access (e.g., on the corporate } \\
\text { intranet) without compromising information } \\
\text { security. }\end{array}$ \\
The design of process models & $\begin{array}{l}\text { Capture relevant information for specific } \\
\text { purposes, for example risk annotations for } \\
\text { risk management, or job descriptions for HR } \\
\text { management. }\end{array}$ \\
Role-based process models & $\begin{array}{l}\text { That only allow stakeholders to see those models } \\
\text { that are relevant to them. }\end{array}$ \\
\hline
\end{tabular}
Source: based on Franz, Kirchmer, \& Rosemann (2012).

Knowledge Management should be based on three fundamental pillars: people, technology, and processes (Table 2). A major role in Knowledge Management is played by information technologies, management systems, attitudes of the staff, and organizational cultures that arouses enthusiasm and eagerness in staff members, which contribute to knowledge sharing and the creation of so-called 'project teams' (Alavi \& Leidner, 2001; Andreeva \& Kianto, 2012; Barnes \& Milton, 2014; , Bartol \& Srivastava, 2002). The strategy pursued by an organization, its employees, technology, and organizational culture underlie the process of Knowledge Management, in particular: creation, codification, and transfer of knowledge.

Business Process Management in an organization should take into consideration the knowledge resources that it possesses in order to ensure that employees have access to knowledge about specific tasks performed as part of a particular business process (Maier \& Remus, 2002). 
Table 2. Characteristics of business processes

\begin{tabular}{ll}
\hline Type of business process & Characteristics \\
\hline Knowledge-intensive & $\begin{array}{l}\text { The processes are often considered complex in } \\
\text { general, with many, but conceptually simple, (usually) } \\
\text { document-centred activities; at the heart of these } \\
\text { processes are a few central decision steps which } \\
\text { require personal judgment based on experience, } \\
\text { a comprehensive knowledge about the given as well } \\
\text { as about older, similar cases, access to much specific } \\
\text { information manifold legal regulation and standard } \\
\text { operating procedures. } \\
\text { The processes under consideration normally consist } \\
\text { of many steps performed by many people in different } \\
\text { roles; often several departments are involved, } \\
\text { sometimes in different locations, etc. Though legal } \\
\text { regulations prescribe the departments and/or roles } \\
\text { to be involved, the specific sequence of processing } \\
\text { steps may vary for specific instances due to particular } \\
\text { exceptions, or complications. Even if the business } \\
\text { process is determined completely, complex, not } \\
\text { formally modelled decision processes may be } \\
\text { embedded in black boxes, or the process may change } \\
\text { during its enactment. }\end{array}$ \\
\hline Source: Papavassiliou \& Mentzas (2003).
\end{tabular}

The key factors causing all processes in an organization to run smoothly are learning and cooperation. Therefore, the processes occurring in an organization should be increased based on individual, team, and organizational knowledge and, consequently, they become more and more flexible as well as adjusting to the changing environmental conditions. Each organization should collect knowledge on the processes that take place within it.

Moreover, employees should play an active role in shaping the course of processes and the implementation of changes in an enterprise (Long, Jung, Choi, \& Song, 2007; Tiago, Couto, Tiago, \& Vieira, 2007). A new motivation system which is designed for teamwork should be developed, which would stimulate the striving for increased efficiency as well as the transfer of knowledge among team members (Choi, Poon, \& Davis, 2008; Donate \& de Pablo, 2015). Knowledge as the main resource of an organization may not be put to good use if employees compete with one another while hiding information and not sharing their skills. Teamwork helps to improve qualifications. The main advantage arising from the adoption of the model of Knowledge Management is that it allows users to avoid an excess of 
information, increase the usefulness of knowledge, and concentrate on the information that is of key importance for the value chain (Jung, Choi, \& Song, 2007). Due to the information-related significance of process models, advanced support tools should also have the feature of publishing the contents for the purposes of an organization. This may take the form of a simple export of the graphic representations of process diagrams into files, however, it is often possible to present the whole models as process portals. They are kept in intranet networks and allow the authorized members of an organization to look through the selected images of the process map and access their attributes.

To use the synergies of Knowledge Management and Business Process Management, it is necessary to enable the use of knowledge not only during the design and the analysis stages of the processes performed, but above all during their implementation. According to U. Remus, knowledge-oriented Knowledge Management is necessary, while at the same time consciously shaping of business processes, so that they use and support Knowledge Management (Maier \& Remus, 2002).

If appropriate organizational conditions are created, and in addition the awareness of the management and the staff is awoken, it allows the diffusion of knowledge which contributes to the development of innovative ideas and solutions (Chen \& Huang, 2009; Darroch, 2005; Du Plessis, 2007; Hislop, 2013; Hsu \& Shen, 2005). The successful promotion of new ideas, effective acquisition and sharing of good practices, and integration of various areas of specialist knowledge, altogether, they create conditions for the development and growth of a company (Tiago, Couto, Tiago, \& Vieira, 2007; Wen, 2009).

The primary benefit of using process-oriented Knowledge Management is that it helps users avoid information overload, increases knowledge usability, and focuses on information that is essential to the value chain (Jung, Choi, \& Song, 2007). The benefits of implementing a Knowledge Management process include, among others, providing knowledge resources to the right people at the right place and time, facilitating the search for and applying specialized knowledge and know-how, supporting cooperation, communication, knowledge sharing, continuous learning and the improvement of both individual employees as well as the entire organization (Bitkowska, 2019b).

It is assumed that business processes are used to achieve the goals of the organization, and that knowledge and data are developed in accordance with these goals, and are also their output. Thanks to the learning process of the organization, based on the continuous selection, collection and analysis of knowledge resources obtained during the implementation of business processes, there is both knowledge development and process improvement. 
In practice, the so-called industry reference models serve as guidelines in introducing Business Process Management in enterprises. Reference models represent knowledge that can be used depending on the application of the model, and can create a structured and methodological framework (Process Classification Framework - PCF).

\section{RESEARCH METHODOLOGY AND RESULTS}

Empirical research has been carried out on a sample of 122 companies operating in Poland in 2019. A selection of companies in the study was performed by the method of target screening, taking into account only organizations that have implemented and adopted Business Process Management. The main criterion was whether an organization adopts BPM, however, the number of employees and economic situation were also taken into consideration. Poland is one of the developing countries in Eastern Europe and is, at the same time, a member of the European Union. So far there has been no research on the modeling of the process of Knowledge Management in process organizations.

An important criterion for the division of the companies under examination was the number of employees. The companies under analysis were classified into the following groups: small enterprises - 10-49 people (24.60\%), medium-sized enterprises - 50-249 people $(24.60 \%)$, and large ones -250 or more people $(50.80 \%)$. The survey questionnaire was filled in by management staff, executives, owners, process managers, experts in BPM, representatives of quality management, members of process offices, business analysts, and project managers.

The reasons given for the implementation of Business Process Management (Table 3 ) seem important. The most common reasons provided by the respondents were: improving the effectiveness of achieving strategic and operational goals, coordination of BPM, cost rationalization, faster reaction to client needs and expectations of improvement in their competitive position, an increase in innovation, and a rise in revenues and profits.

In those organizations that use BPM, respondents pointed to various reasons for its implementation The most frequently reported reasons included: improvement in their competitive position (51.00\%), implementation of ISO standards (49.00\%), faster response to the needs and expectations of clients (44.10\%), implementation of an IT system (36.30\%) and increased flexibility of the organization's operation (36.30\%). Also important were: the ability to react quickly to changes in the market environment (34.3\%), cost 
reduction (31.40\%), and an increase in revenues and profits $(31.40 \%)$. The least attention was paid to the development of employees (17.60\%).

For comparison, global research has shown that enterprises implement BPM in a comprehensive and orderly manner. The main premises associated with its use included primarily cost reduction and improved process efficiency (53\% in 2017, 53\% in 2015 and 35\% in 2013), coordination of management processes (36\% in 2017, 30\% in 2015 and 35\% in 2013), improving existing products or creating new ones (28\% in 2017, 33\% in 2015 and 34\% in 2013), as well as improving IT resource management (26\% in 2017 and 15\% in 2015). Other factors related to supervision and control (21\% in 2017, 17\% in 2015 and $15 \%$ in 2013) and changes in organizational culture (15\% in 2017 and $17 \%$ in 2015) (Harmon, 2018).

Table 3. Reasons for the implementation of Business Process Management (in \%)

\begin{tabular}{|c|c|c|c|c|}
\hline Response & Total & $\begin{array}{l}\text { The number } \\
\text { of employed } \\
\text { people } \\
10-49\end{array}$ & $\begin{array}{l}\text { The number } \\
\text { of employed } \\
\text { people } \\
50-249\end{array}$ & $\begin{array}{l}\text { The number } \\
\text { in \% of } \\
\text { employed } \\
\text { people } \\
\text { above } 249\end{array}$ \\
\hline $\begin{array}{l}\text { Improving the effectiveness of } \\
\text { achieving strategic and operational } \\
\text { goals }\end{array}$ & 42.62 & 20.20 & 32.60 & 47.20 \\
\hline Coordination of BPM & 42.62 & 20.10 & 34.90 & 45.00 \\
\hline Rationalization/cost reduction & 40.98 & 19.50 & 22.30 & 58.20 \\
\hline $\begin{array}{l}\text { Faster response to customer needs } \\
\text { and expectations/increased flexibility }\end{array}$ & 36.89 & 15.10 & 27.10 & 58.80 \\
\hline $\begin{array}{l}\text { Ability to quickly respond to changes } \\
\text { in the market environment }\end{array}$ & 29.51 & 18.20 & 18.90 & 62.90 \\
\hline $\begin{array}{l}\text { Supervision and control, risk } \\
\text { management. Creation of } \\
\text { unambiguous management principles } \\
\text { and control mechanisms and division } \\
\text { of responsibilities }\end{array}$ & 27.87 & 12.20 & 31.60 & 56.20 \\
\hline $\begin{array}{l}\text { Improving existing products, creating } \\
\text { new products or introducing new } \\
\text { business lines }\end{array}$ & 26.23 & 20.10 & 30.90 & 49.00 \\
\hline Implementation of an IT system & 25.41 & 17.50 & 23.30 & 59.20 \\
\hline Implementation of ISO standards & 20.49 & 13.10 & 32.10 & 55.80 \\
\hline
\end{tabular}

Source: own work, based on empirical research carried out in 2019.

The introduction of Business Process Management into organizations results from the requirements imposed by the changing environmental conditions and is, first and foremost, intended to develop organizations and 
help them face the competition. The percentage of such organizations is large and very similar in each case under discussion. An inseparable element of the functioning of Business Process Management is the use of dedicated IT tools. The results of the analysis of the research concerning the Business Process Management lifecycle are presented in Table 4. Process optimization was declared by $65.57 \%$ of the surveyed enterprises, identification of processes $54.92 \%$, controlling of processes was stated by $52.46 \%$ of the surveyed organizations, while process modelling was identified by $41.80 \%$.

Table 4. The lifecycle of Business Process Management (in \%)

\begin{tabular}{lclll}
\hline & Total & $\begin{array}{l}\text { The } \\
\text { number of } \\
\text { employed } \\
\text { people } \\
\text { Response }\end{array}$ & $\begin{array}{l}\text { The } \\
\text { number } \\
\text { in of } \\
\text { employed } \\
\text { people } \\
\mathbf{5 0 - 2 4 9}\end{array}$ & $\begin{array}{l}\text { The } \\
\text { number of } \\
\text { employed } \\
\text { people } \\
\text { above 249 }\end{array}$ \\
\hline $\begin{array}{l}\text { Optimization/improvement } \\
\text { of processes }\end{array}$ & 65.57 & 12.20 & 31.60 & 56.20 \\
$\begin{array}{l}\text { Identification of processes } \\
\text { Process controlling }\end{array}$ & 54.92 & 10.10 & 44.90 & 45.00 \\
$\begin{array}{l}\text { Process modelling } \\
\text { Process simulation }\end{array}$ & 52.46 & 15.50 & 26.30 & 58.20 \\
\hline SOurc: & 41.80 & 10.10 & 26.10 & 64.80 \\
& 23.77 & 61.90 & 19.90 & 18.20 \\
\hline
\end{tabular}

Source: own work, based on empirical research carried out in 2019.

The Knowledge Management process was implemented by $22.13 \%$ of the surveyed organizations. The most common subprocesses are: use of knowledge (59.84\%), sharing knowledge (56.56\%) and creating knowledge $(55.74 \%)$. The less common occurrences of Knowledge Management are its localization (31.97\%), dissemination of knowledge (30.33\%), and storage of knowledge (28.69\%) (Table 5).

It should be stressed that BPM has exerted a considerable influence over the improvement of the quality of work both inside and outside an organization. An appropriate organizational climate and a willingness to develop the organization, generate the Knowledge Management process. In a process-based organization, it is necessary to create proper relations driven by cooperation and joint action, which has a positive influence on the modelling of Knowledge Management processes. 
Table 5. The subprocesses of the model of the process of Knowledge Management (in \%)

\begin{tabular}{|c|c|c|c|c|}
\hline Response & Total & $\begin{array}{l}\text { The } \\
\text { number of } \\
\text { employed } \\
\text { people } \\
10-49\end{array}$ & $\begin{array}{l}\text { The } \\
\text { number of } \\
\text { employed } \\
\text { people } \\
50-249\end{array}$ & $\begin{array}{l}\text { The } \\
\text { number of } \\
\text { employed } \\
\text { people } \\
\text { above } 249\end{array}$ \\
\hline The use of knowledge & 59.84 & 23.20 & 32.60 & 44.20 \\
\hline Sharing knowledge & 56.56 & 20.10 & 34.90 & 45.00 \\
\hline $\begin{array}{l}\text { Developing/creating } \\
\text { knowledge }\end{array}$ & 55.74 & 18.50 & 23.30 & 58.20 \\
\hline Acquiring knowledge & 44.26 & 16.10 & 26.10 & 58.80 \\
\hline Locating knowledge & 31.97 & 18.20 & 18.90 & 62.90 \\
\hline $\begin{array}{l}\text { Dissemination of } \\
\text { knowledge }\end{array}$ & 30.33 & 12.20 & 31.60 & 56.20 \\
\hline Storage of knowledge & 28.69 & 20.10 & 30.90 & 49.00 \\
\hline
\end{tabular}

Companies have noticed that implementing the Knowledge Management process brings some benefits. First and foremost, it was possible to use collected knowledge more extensively as well as assess, document, and gathered it; moreover, knowledge was shared among employees who learned and developed their competencies (Table 6).

The challenge for modern process organizations is the constant accumulation of knowledge and its skillful use in order to gain a competitive advantage and ensure a stable position in the market. Knowledge Management in an organization is closely related to Business Process Management. The use of this concept makes it possible to improve the competitiveness of enterprises, and continuously improve and develop. Medium and small process organizations present a greater involvement in Knowledge Management than microorganisms. The identification, acquisition, presentation and documentation of knowledge are not independent tasks, but are implemented within economic processes. Team cooperation helps in improving qualifications. The implementation of Knowledge Management stimulates employee creativity and supports internal communication. Building a process organization using best practices and guidelines minimizes the risk of failure of projects to improve the organization and implement Knowledge Management. Business Process Management in organizations should take into account their knowledge resources which provide employees with knowledge about specific tasks within the implementation of individual business processes. 
Table 6. The benefits arising from implementing the process of Knowledge Management (in \%)

\begin{tabular}{|c|c|c|c|c|}
\hline Response & Total & $\begin{array}{l}\text { The } \\
\text { number of } \\
\text { employed } \\
\text { people } \\
10-49\end{array}$ & $\begin{array}{l}\text { The } \\
\text { number of } \\
\text { employed } \\
\text { people } \\
50-249\end{array}$ & $\begin{array}{l}\text { The } \\
\text { number of } \\
\text { employed } \\
\text { people } \\
\text { above } 249\end{array}$ \\
\hline $\begin{array}{l}\text { Sharing knowledge/ } \\
\text { process experience }\end{array}$ & 46.72 & 20.20 & 32.60 & 47.20 \\
\hline $\begin{array}{l}\text { Collection/use of } \\
\text { knowledge about the } \\
\text { processes/trial experience }\end{array}$ & 36.07 & 19.10 & 35.90 & 45.00 \\
\hline $\begin{array}{l}\text { Cooperation between } \\
\text { process managers }\end{array}$ & 43.44 & 17.50 & 22.30 & 60.20 \\
\hline $\begin{array}{l}\text { Motivating process } \\
\text { owners/process team } \\
\text { members to share } \\
\text { knowledge }\end{array}$ & 22.13 & 13.10 & 29.10 & 58.80 \\
\hline $\begin{array}{l}\text { Appropriate } \\
\text { communication and } \\
\text { information flow in the } \\
\text { process team }\end{array}$ & 45.90 & 18.20 & 22.90 & 58.90 \\
\hline $\begin{array}{l}\text { A database of specialists } \\
\text { and process/project } \\
\text { experts }\end{array}$ & 23.77 & 11.20 & 32.60 & 56.20 \\
\hline $\begin{array}{l}\text { The ability to train } \\
\text { employees/ managers } \\
\text { in the field of analyzing, } \\
\text { redesigning and improving } \\
\text { processes }\end{array}$ & 28.69 & 20.10 & 30.90 & 49.00 \\
\hline $\begin{array}{l}\text { Building awareness related } \\
\text { to the use of knowledge in } \\
\text { processes }\end{array}$ & 23.77 & 19.50 & 21.30 & 59.20 \\
\hline $\begin{array}{l}\text { Employees can make } \\
\text { changes to processes } \\
\text { according to customer } \\
\text { requirements }\end{array}$ & 22.13 & 10.10 & 32.10 & 58.80 \\
\hline
\end{tabular}

In order to test the correlations between Business Process Management and the Knowledge Management process Yule's, Pearson's, and Bykowski's coefficients have been used. Inferences concerning the main hypothesis, point to the fact that Business Process Management has a positive influence 
over Knowledge Management (Yule's coefficient 0.95, Pearson's coefficient 0.81 and Bykowski's coefficient 0.79) (Bitkowska, 2019b).

Analysis of all the correlations under examination shows that Yule's coefficient indicates a high convergence of each studied attribute and the use of the Knowledge Management process. The reason for this is that all the phenomena are heavily dependent on one another; they are closely related. The indication testifies to a strong correlation among the attributes. Inferences concerning the main hypothesis, point to the fact that Business Process Management has a moderate, positive influence over the Knowledge Management process.

\section{CONCLUSIONS}

Business Process Management is treated as an up-to-date approach to an organization's operation, while process structures offer a sense of order. It is easier for organizations using Business Process Management to model Knowledge Management processes; knowledge is collected in databases of processes in repositories (Bitkowska, 2019b). There are knowledge resources and they are used, modified, shaped, and perpetuated. There are also relations based on knowledge sharing, which are part of the informal organizational culture. The preparation of the Knowledge Management process is intended to systematize these informal rules and relations that exist in process-based organizations and make them objective. The aim is to acquire, process, store, and distribute knowledge. The most significant actions in this context should be oriented at the adoption of IT systems supporting the modelling of the process of Knowledge Management. IT tools are supposed to ensure that the Knowledge Management process is run effectively. by being introduced into knowledge process management (i.e., planning, coordinating, monitoring, and accounting for) and the organizational culture (Bitkowska, 2017; Bitkowska, 2019b). In turn, this fosters training and builds cooperation among staff members. Coping with this sphere, and its operationalization by means of specific strategic, structural, technological, and personal solutions, constitutes a challenge for each and every process-based organization.

The adoption of this concept allows for improvement in the competitiveness of enterprises and ensures continual advancement and development. Modelling of the Knowledge Management process aids companies in determining and deciding on priorities as well as the objectives of remedial projects, and offers incentives to identify the necessary actions that need to be taken in order to develop innovativeness (Bitkowska, 2017). If a process- 
based organization is built on the best practices and guidelines, the risk of failure of projects intended to improve the organization and implement the model of Knowledge Management is minimized. The social factor needs to be taken into consideration as well as the technological one, by way of using IT tools from the perspective of the strategy that is being followed. The analysis that has been performed and the resultant conclusions may be applicable in other European countries or other organizations which intend to implement the process of Knowledge Management. The findings also indicate that ICT practices improve financial performance only when they are coupled with HRM practices (Bitkowska, 2017).

The findings of this study have several important implications for project managers who wish to initiate successful KM practices within their projects. The present study was concerned with organizations operating in Poland, which have introduced Business Process Management. To a smaller extent, the deliberations will also be applicable to microenterprises, to companies that are only just beginning to operate, and to the ones that do not adopt modern management concepts and advanced IT tools (Bitkowska, 2017). There is a need to undertake further research action regarding, e.g., a comparative analysis of European countries. Fast development of software supporting BPM indicates that it is reasonable to study this issue in the context of Knowledge Management. Certainly, knowledge-related implementations must be based both on the right tools and take into account the social factor as well as the strategy that an organization follows. A synergistic effect is to be expected within the system of Knowledge Management. This is a practical implication for managers. The deliberations presented in this paper lead to a conclusion that there is a need to conduct further and a more in-depth literature study as well as empirical research regarding the issues in question, taking into account specific sectors of operation of process-based companies, or continue research with respect to other European countries.

\section{References}

Alavi, M., \& Leidner, D. (2001). Knowledge management and knowledge management systems: Conceptual foundations and research issues. MIS Quarterly, 25(1), 107-136. https://doi.org/10.2307/325096

Antonucci, Y. L., \& Goeke, R. J. (2011). Identification of appropriate responsibilities and positions for business process management success. Seeking a valid and reliable frame-work. Business Process Management Journal, 17(1), 127-146. https://doi.org/10.1108/14637151111105616

Andreeva, T., \& Kianto, A. (2012). Does knowledge management really matter? Linking knowledge management practices, competitiveness and 
economic performance. Journal of Knowledge Management, 16(4), 617 636. https://doi.org/10.1108/13673271211246185

Barnes, S., \& Milton, N. (2014). Designing a successful KM strategy: A guide for the knowledge management professional. Retrieved from https:// haman.academy/wp-content/uploads/2018/02/Designing-a-successfulKM-strategy-By-Milton.pdf https://doi.org/10.1108/lm-06-2015-0046

Bartol, K., \& Srivastava, A. (2002). Encouraging knowledge sharing: The role of organizational reward systems. Journal of Leadership and Organization Studies, 19(1), 64-76. https://doi.org/10.1177/107179190200900105 Bitkowska, A. (2019a). Od Klasycznego do Zintegrowanego Zarzadzania Procesowego. Warszawa: C.H. Beck.

Bitkowska A., (2019b). Business process management vs modeling of the process of knowledge management in contemporary enterprises. In C. Di Ciccio, R. Gabryelczyk, L. García-Bañuelos,T. Hernaus, R.I. Hull, M. Stemberger et al. (Eds.), Business Process Management: Blockchain and Central and Eastern Europe Forum. Lecture Notes in Business Information Processing, 361. Cham: Springer. https://doi.org/10.1007/978-3-03030429-4 22

Bitkowska, A. (2017). Business processes modelling in knowledge management perspective. Przedsiębiorstwo we Współczesnej Gospodarce - Teoria i Praktyka, 2(21), 7-16. https://doi.org/10.19253/reme.2017.02.001

Bitkowska, A. (2013).Zarzq̨dzanie Procesowe we Współczesnych Organizacjach [Process Management in Contemporary Organizations]. Warszawa: Difin. Bosilj-Vukšic, V. (2006). Business process modeling: A foundation for knowledge management. Journal of Information and Organizational Sciences, 30(2), 185-198.

Burlton, R. (2001). Business Process Management: Profiting from Process. Indiana, USA: SAMS.

Chen, C. J., \& Huang, J. W. (2009). Strategic human resource practice and innovation performance - the mediating role of knowledge management capacity. Journal of Business Research, 62(1), 104-114. https://doi. org/10.1016/j.jbusres.2007.11.016

Choi, B., Poon, S. K., \& Davis, J. G. (2008). Effects of knowledge management strategy on organizational performance: A complementarity theorybased approach. Omega, 36, 235 - 251. https://doi.org/10.1016/j. omega.2006.06.007

Darroch, J. (2005). Knowledge management, innovation and firm performance. Journal of Knowledge Management, 9(3), 101-115. https://doi.org/10.1108/13673270510602809

Davenport, T. H. (1993). Process Innovation: Reengineering Work Through Information Technology. Cambridge: Harvard Business School Press. https://doi.org/10.1111/j.1467-9310.1995.tb01348.x

Davenport, T. H., \& Short, J. E. (1990). The new industrial engineering. information technology and business process redesign. Sloan Management Review, 31, 11-27. 
Davenport, T., \& Prusak, L., (1997). Working Knowledge: How Organizations Manage What They Know. Boston: Harvard Business School Press. https://doi.org/10.1108/nlw.2000.101.6.282.4

Donate, M. J., \& Sánchez de Pablo J. D. (2015). The role of knowledgeoriented leadership in knowledge management practices and innovation. Journal of Business Research, 68, 360-370. https://doi.org/10.1016/j. jbusres.2014.06.022

Dumas, M., van der Aalst, W. M. P., \& Hofstede, A. H. M. (Eds.). (2005). Process-Aware Information Systems: Bridging People and Software Through Process Technology. Hoboken, New Jersey: John Wiley \& Sons. https://doi.org/10.1002/0471741442

Du Plessis, M. (2007). The role of knowledge management in innovation. Journal of Knowledge Management, 11(4), 20-29. https://doi. org/10.1108/13673270710762684

Franz, P. H., Kirchmer, M., \& Rosemann, M. (2012). Value-driven business process management. Retrieved from https://www.accenture.com/mxes/ /media/accenture/conversion-assets/dotcom/documents/local/esla/pdf2/accenture-value-driven-business-process-management.pdf

Gabryelczyk, R., \& Roztocki, N. (2018). Business process management success framework for transition economies. Information Systems Management, 35(3), 234-253. https://doi.org/10.1080/10580530.2018 .1477299

Gavrilova, T., Alsufiev, A., \& Pleshkova, A. (2017). Influence of knowledge management practices on company performance results in Russian context. Retrieved from WP_6(E)-2017_Gavrilova_Alsufiev_Pleshkova.pdf

Gierszewska, G. (2011), Zarzqdzanie Wiedzq w Przedsiębiorstwie. Warszawa: Oficyna Wydawnicza Politechniki Warszawskiej.

Gierszewska, G. (Ed.). (2018). Co Dalej z Zarządzaniem? Warszawa: Wydawnictwo Politechniki Warszawskiej.

Handzic, M. (2017). The KM times they are a-changin'. Journal of Entrepreneurship, Management and Innovation, 13(3), 7-27. https://doi. org/10.7341/20171331

Harmon, P. (2003). Business Process Change: A Manager's Guide to Improving, Redesigning, and Automating Processes. Amsterdam et al.: Morgan Kaufmann Publishers.

Harmon, P. (2007). Business Process Change. Amsterdam et al.: Morgan Kaufmann Publishers.

Harmon, P., (2018). The State of Business Process Management 2018. Retrieved from: http://www. bptrends.com

Hislop, D. (2013). Knowledge Management in Organizations: A Critical Introduction. New York: Oxford University Press.

Hsu, S. H., \& Shen, H. P. (2005). Knowledge management and its relationship with TQM. Total Quality Management, 16(3), 351-361. https://doi. org/10.1080/14783360500054111 
Ho, C. F., Hsieh, P. H., \& Hung, W. H. (2014). Enablers and processes for effective knowledge management. Industrial Management \& Data Systems, 114(5), 734-754. https://doi.org/10.1108/imds-08-2013-0343

Indulska, M., Green, P., Recker, J. C., \& Rosemann, M. (2009). Business process modelling: Perceived benefits. In 28th International Conference on Conceptual Modelling (pp. 9-12). November Gramado, Brazil. https:// doi.org/10.1007/978-3-642-04840-1_34

Jeston, J., \& Nelis, J. (2014). Business Process Management: Practical Guidelines to Successful Implementations. London and New York, NY: Routledge.

Jung, J., Choi I., \& Song, M. (2007). An integration architecture for, Knowledge Management systems and Business Process Management systems. Computers in Industry, 58(1), 21-34. https://doi.org/10.1016/j. compind.2006.03.001

Kluza, K., Wiśniewski, P., Jobczyk, K., Ligeza, A., \& Suchenia, A. (2017). Comparison of selected modeling notations for process, decision and system modeling. In Proceeding of the Federated Conference on Computer Science and Information Systems (FedCSIS). IEEE. https://doi. org/10.15439/2017f454

Ko, R. K. L., Lee, S. S. G., \& Lee, E. W. (2009). Business process management (BPM) standards: A survey. Business Process Management Journal, 15(5), 744-791. https://doi.org/10.1108/14637150910987937.

Liao, S. H., \& Wu, C. C. (2010). System perspective of knowledge management, organizational learning, and organizational innovation. Expert Systems with Applications, 37(2), 1096-1103. https://doi.org/10.1016/j. eswa.2009.06.109

Lin, H. F. (2007). Knowledge sharing and firm innovation capability: An empirical study. International Journal of Manpower, 28(3/4), 315-332. https://doi.org/10.1108/01437720710755272

Linderman, K., Schroeder, R. G., \& Sanders J. (2010). A knowledge framework underlying process management. Decision Sciences, 41(4), 689-719. https://doi.org/10.1111/j.1540-5915.2010.00286.x

Lundvall, B. A., \& Nielsen, P. (2007). Knowledge management and innovation performance. International Journal of Manpower, 28(3/4), 207-223. https://doi.org/10.1108/01437720710755218

Madison, D. (2005). Process Mapping, Process Improvement, and Process Management. California: PatonPress.

Maier, R., \& Remus, U. (2002). Defining process-oriented knowledge management strategies. Journal of Knowledge Management, 9(2), 103118. https://doi.org/10.1002/kpm.136

Malinova, M., \& Mendling, J. (2018). Identifying do's and don'ts using the integrated business process management framework. Business Process Management Journal, 24(4), 882-899. https://doi.org/10.1108/bpmj10-2016-0214 
Martínez-Martínez, A., Suárez, L. M. C., Montero, R. S., \& del Arco, E. A. (2018). Knowledge management as a tool for improving business processes: An action research approach. Journal of Industrial Engineering and Management, 11(2), 276-289. https://doi.org/10.3926/jiem.2499

Mejssner, B. (2018). Cyfryzacja firmy zaczyna się od zarządzania procesami. Retrieved from https://www.computerworld.pl/news/Cyfryzacja-firmyzaczyna-sie-od-zarzadzania-procesami,409354.html

Nonaka, I., \& Takeuchi, H. (1995). The Knowledge Creating Company: How Japanese Companies Create the Dynamics of Innovation. New York: Oxford University Press. https://doi.org/10.1016/0024-6301(96)81509-3

Papavassiliou, G., \& Mentzas, G. (2003). Knowledge modelling in weaklystructured business processes. Journal of Knowledge Management, 7(2), 18-33. https://doi.org/10.1108/13673270310477261

Paschek, D, Ivascu L., \& Draghici A (2018). Knowledge management-the foundation for a successful business process management. ProcediaSocial and Behavioral Sciences, 238, 182-191. https://doi.org/10.1016/j. sbspro.2018.03.022

Pastuszak, Z., \& Chadam, J. (2013). Acquisitions: How should a project be successfully executed. Industrial Management \& Data Systems, 113(9), 1270-1285. https://doi.org/10.1108/imds-01-2013-0042

Probst, G., Raub, S., \& Romhardt, K. (2000). Managing Knowledge. Building Blocks for Success. London: Wiley.

Process Classification Framework PCF, APQC Cross Industry. Retrieved from https://www.apqc.org

Pyzdek, T., \& Keller, P. (2009). The Six Sigma Handbook. London: McGraw-Hill. Rabhi, F. A., Yu, H., Dabous, F. T., \& Wu, S. Y. (2007). A service-oriented architecture for financial business processes: A case study in trading strategy simulation. Information Systems and E-Business Management, 5, 185-200. https://doi.org/10.1007/s10257-006-0041-x

Rehman, W., Asghar N., \& Ahmad, K. (2015). Impact of KM practices on firms' performance: A mediating role of business process capabilities and organizational learning. Pakistan Economic and Social Review, 53(1), 47-80.

Recker, J., Rosemann, M., Indulska, M., \& Green, P. (2009). Business process modelling: A comparative analysis. Journal of the Association for Information Systems, 10, 333- 363. https://doi.org/10.17705/1jais.00193

Richter-von Hagen, C., Ratz, D., \& Povalej, R. (2005). A genetic algorithm approach to self-organizing knowledge intensive processes. In Proceedings of I-KNOW '05, Graz, Austria, June, 29- July 1. Retrieved from http://citeseerx.ist.psu.edu/viewdoc/download?doi=10.1.1.128.1 605\&rep=rep1\&type=pdf

Rosemann, M., \& vom Brocke, J. (2010). The Six Core Elements of Business Process Management. In Handbook of Business Process Management. Berlin: Springer. 
Rummler, G. A., \& Brache A. P. (1995). Improving Performance: How to Manage the White Space in the Organization Chart. San Francisco: Jossey-Bass Publishers.

Silver, B. (2011). BPMN Method \& Style. 2nd edition. Altadena, USA: CodyCassidy Press.

Smith, H., \& Fingar, P. (2003). Business Process Management: The Third Wave. Tampa, Florida, USA: Meghan-Kiffer Press.

Spanyi, A. (2005). More for Less: The Power of Process Management. Tampa, Florida, USA: Meghan-Kiffer Press.

Sun, P. (2010). Five critical knowledge management organizational themes. Journal of Knowledge Management, 14(4), 507-523. https://doi.org/10.1108/13673271011059491

Tiago, M. T. B., Couto, J. P. A., Tiago, F. G., \& Vieira, A. C. (2007). Knowledge management: An overview of European reality. Management Research News, 30(2), 100-114. https://doi.org/10.1108/01409170710722946

Trocki, M. (2016). Inteligencja procesowa, czyli inteligentne zarządzanie procesowe. Studia i Prace Kolegium Zarzqdzania i Finansów Szkoły Głównej Handlowej, 149, 171-184.

Warnecke, G., Gissler, A., \& Stammwitz, G. (1998). Referenzmodell wissensmanagement: Ein Ansatz zur Modellbasierten Gestaltung Wissensorientierter Prozesse. Information Management and Consulting, 1, 9-24.

Wen, Y. F. (2009). An effectiveness measurement model for knowledge management. Knowledge-Based Systems, 22(5), 363-367. https://doi. org/10.1016/j.knosys.2009.02.007

Wiig, K. M. (1995). Knowledge Management Methods: Practical Approaches to Managing Knowledge. Arlington, TX: Schema Press.

Zhu, P. (2015). Knowledge Management (KM) vs. Business Process Management (BPM). Retrieved from http://futureofcio.blogspot. de/2013/10/knowledge-management-km-vs-business.html

Zięba, M. (Ed.). (2017). Knowledge management - Current trends and challenges. Journal of Entrepreneurship, Management and Innovation, 13(3). Retrieved from https://jemi.edu.pl/uploadedFiles/file/all-issues/ vol13/issue3/JEMI_Vol13_Issue3_2017_From_The_Editor.pdf

Żytniewski, M. (2016). Integration of knowledge management systems and business processes using multi-agent systems. International Journal of Computational Intelligence Studies 5(2), 180-196. https://doi. org/10.1504/ijcistudies.2016.077131

Żytniewski, M. (2017). Context specification in support of business processes and knowledge management integration. International Conference on Information Systems Architecture and Technology. Cham: Springer. https://doi.org/10.1007/978-3-319-67223-6_15 


\begin{abstract}
Abstrakt
Integracja koncepcji zarzqdzania procesowego (BPM) i zarzqdzania wiedzq (KM) stanowi aktualny problem badawczy, który należy przeanalizować w przedsiębiorstwach. Wyzwaniem dla współczesnych organizacji procesowych jest ciagłe gromadzenie wiedzy i umiejętne jej wykorzystywanie w celu uzyskania przewagi konkurencyjnej i zapewnienia stabilnej pozycji na rynku. Pomimo rosnacego zainteresowania badaczy i praktyków brakuje artykułów dotyczq̨cych omawianej problematyki. Głównym celem artykułu jest identyfikacja zwiqzzu między zarzqdzaniem procesowym a zarzqdzaniem wiedzq. W artykule przedstawiono wyniki badań empirycznych przeprowadzonych przez we wspótczesnych przedsiębiorstwach w 2019 r. w Polsce, a także korzyści zwiqzane z korelacja tych dwóch pojęć. Zarzqdzanie procesowe ma pozytywny wpływ na zarzqdzanie wiedzq, a w szczególności procesy zarzqdzania wiedzq. Identyfikacja, pozyskiwanie, prezentacja i dokumentacja wiedzy nie sq niezależnymi zadaniami, ale sq realizowane $w$ ramach procesów. Wdrożenie zarzqdzania wiedzq stymuluje kreatywność pracowników i wspiera komunikację wewnętrznq. Budowanie organizacji procesowej przy użyciu najlepszych praktyk i wytycznych minimalizuje ryzyko niepowodzenia projektów $w$ celu poprawy organizacji $i$ wdrożenia zarzq̨dzania wiedzq. Do przetestowania korelacji między koncepcjq zarzqdzania procesowego i zarzqdzania wiedzq wykorzystano współczynniki Yule'a, Pearsona i Bykowskiego.
\end{abstract}

Słowa kluczowe: zarzq̨dzanie procesowe, zarzq̨dzanie wiedzq, proces zarzqdzania wiedzq

\title{
Biographical note
}

Agnieszka Bitkowska works as an associated professor at the Faculty of Management at the Warsaw University of Technology in Chair of Process Management. Her scientific specialty is the application of business process management and change management in contemporary enterprises. She is the author of several publications in the field of business process management, integrated business process management, knowledge management, project management and cooperation networks. 